\title{
The effect of intellectual intelligence and adversity quotient on learning motivation
}

\author{
Samsilayurni Samsilayurni ${ }^{\left.{ }^{*}\right)}$, Gunawan Ismail ${ }^{1}$, Nipriansyah Nipriansyah $^{2}$, Edy Susanto $^{3}$, Elsa Viona $^{4}$ \\ ${ }^{1}$ Universitas Muhammadiyah Palembang, Indonesia \\ ${ }^{2}$ SPNF SKB Kaur Bengkulu, Indonesia \\ ${ }^{3}$ Universitas Dehasen Bengkulu, Indonesia \\ ${ }^{4}$ Universitas Bengkulu, Indonesia
}

\begin{tabular}{l}
\hline Article Info \\
\hline Article history: \\
Received Aug $11^{\text {th }}, 2021$ \\
Revised Sept $12^{\text {th }}, 2021$ \\
Accepted Oct $21^{\text {st }}, 2021$ \\
\hline
\end{tabular}

\section{Keyword:}

Intellectual intelligence

Adversity quotient

Learning motivation

\begin{abstract}
The purpose of this study was to analyze the effect of intellectual intelligence and Adversity Quotient on learning motivation State Vocational High School 1 Pasmah Air Keruh. The sample in this study amounted to 96 students. The instrument used in this study was a questionnaire or questionnaire. The data analysis technique used in this research is inferential statistical analysis, correlation test, $\mathrm{T}$ test and $\mathrm{F}$ test. Based on the results of the study, there is a significant influence of intellectual intelligence and adversity quotient together on learning motivation. This means that the higher the level of intellectual intelligence and adversity quotient in students, the more motivating and enthusiastic students are in learning.
\end{abstract}

(C) 2021 The Authors. Published by IICET.

This is an open access article under the CC BY-NC-SA license

(https://creativecommons.org/licenses/by-nc-sa/4.0)

\section{Corresponding Author:}

Samsilayurni Samsilayurni,

Universitas Muhammadiyah Palembang

Email: yurni.samsila66@gmail.com

\section{Introduction}

The demands of the era of globalization, the world of education is expected to improve its quality so that humans can survive and be able to adapt. Education plays an important role in creating behavior, mental in all aspects of life, because education is a benchmark in determining the progress or decline of a country's development (Kristianawati \& Wafirotin, 2018). The function of education in the process of intellectual (intellectual) growth is very large because it can help individuals improve, develop and grow talents, interests and abilities of reason to receive knowledge and skills (Amry, 2020). Many teachers are less creative in teaching in the classroom so as to create an unpleasant learning atmosphere, resulting in students feeling bored in learning and ultimately unable to advance children's intelligence (Mamangkey, 2018). (Akimas \& Bachri, 2016) asserts that intelligence is a person's overall capacity to adapt through effective cognition and information processing. Related to intelligence, teachers must realize the importance of increasing intelligence in various ways and together with colleagues fix various aspects in an effort to increase student intelligence (Srihartini et al., 2021).

Intellectual intelligence is a form of interpreting one's cognitive abilities, such as the ability to act according to goals, being able to think rationally in dealing with the surrounding environment effectively (Ayu \& Pratiwi, 
2020). Another opinion also asserts that intellectual intelligence is a qualification of human intelligence, dominated by the ability to think rationally at approximately 80\% (Pasek, 2017).

To measure and test intellectual intelligence can be done through tests of verbal reasoning, verbal nonreasoning, arithmetic. And the dimensions that make up intellectual abilities include numerical intelligence, verbal understanding, conceptual skills, inductive reasoning, visualization deductive reasoning and good memory (Akimas \& Bachri, 2016) . Intellectual intelligence is closely related to learning motivation, because motivation is able to increase one's intellectual intelligence so that it can make a person excel in learning (High et al., 2019).

In addition to intellectual intelligence that must be possessed by learning individuals is the adversity quotient (Nur Rachmah et al., 2015). Adversity quotient is an individual's intelligence in overcoming every difficulty and this intelligence is often termed as the power of fighting power in the face of adversity (Merianah, 2019). Another explanation for adversity is the ability to turn obstacles into opportunities for success in achieving goals (Srihartini et al., 2021). Regarding a person's intelligence in solving a difficulty or problem, especially students are required to have a strong adversity quotient because this intelligence really supports student success in improving learning achievement, in other words, students who have a high adversity quotient are certainly better able to overcome the difficulties they are facing. In Perri et al., 2018). Another expression confirms the adversity quotient is an individual's ability to face obstacles or difficulties (Arif et al., 2020).

Regarding the intelligence that must be possessed by a person, both intellectual intelligence and adversity quotient are expected to contribute to motivation in learning so that they are able to produce achievements (Benu \& Nugroho, 2021). Motivation is an important component in achieving a result (Thamaria, 2018). Students in addition to having intellectual intelligence, motivation is also important, these roles include directing (directional function), activating and increasing activities (active and energizing function) (Sawaludin, 2021). The essence of learning motivation is to encourage students both internally and externally to students who are studying to make changes in behavior, motivation is a goal and a tool in learning (Wayan Jati Adnyana, Ketut Suma, 2017). Along with the opinion expressed, that high learning motivation is related to student achievement, because strong motivation in students will increase interest, willingness and high enthusiasm in learning (Sarnoto \& Romli, 2019).

This research was conducted in the Empat Lawang district, Pasemah Air Keruh sub-district which is known to be very fertile and is a producer of plantations and rice fields, such as coffee and rice (Saputri, 2013). The development of this region is very strategic, especially in empowering human resources. Efforts to produce quality education must be accompanied by an increase in educational facilities (Hamid, 2018)The condition of the society is very multicultural which consists of various ethnic groups such as; the pasma, latitude, rejang and southern tribes (Gustina \& Ali, 2020). The daily life of the people is very interacting or cultured of mutual respect, respect for customs, religious communities, but the level of education is still low (Hamid, 2018).

There are several previous studies that discuss intellectual intelligence and adversity as follows: Akimas et al. analyzed the Effect of Intellectual Intelligence, Emotional Intelligence, Spiritual Intelligence on the Performance of Inspectorate Employees of South Kalimantan Province. The sample is 81 respondents. The data analysis technique used was multiple linear regression. Significance test using p-value (Akimas \& Bachri, 2016). Furthermore, Srihartati et al. analyzed the effect of adversity intelligence and work performance on teacher professionalism. This type of quantitative correlational research. The sample is 135 people. The results showed that there was a significant influence between adversity intelligence on teacher professionalism. The results of this study imply that adversity intelligence and work performance are two factors that affect teacher professionalism (Srihartini et al., 2021). Pasek in his research on the influence of intellectual intelligence on the level of accounting understanding. Using the explanatory research method, the results show that intellectual intelligence has a positive and significant effect on accounting understanding. This means that with good intellectual intelligence, students will more easily understand accounting understanding (Pasek, 2017).

This research is new, and no previous research has been conducted. This study analyzes intellectual intelligence and adversity quotient on learning motivation simultaneously for vocational high school students in the district of Pasmah Air murky. The difference in this study lies in the analysis between Intellectual Intelligence and Adversity Quotient on student learning motivation at the Vocational High School level. Knowing the level of intellectual intelligence and adversity in students as early as possible is very necessary, because it is assumed that high intellectual intelligence and adversity quotient in students can motivate students to learn, and in the end students will excel. This research contributes to the development of science, especially in the field of developing learning media as a learning tool so that all education managers use the 
media as a tool to spur the level of intelligence, both intellectual and adversity quotient in students so that students motivate to learn.

\section{Method}

This type of research is qualitative using a survey method. The instrument used is a questionnaire or questionnaire, the population in this study is a total of 96 grade 10 students, and this population is used as a sample in this study. Data analysis techniques in this study used inferential statistics, correlation test, $\mathrm{t}$ test and F test.

\section{Results and Discussions}

\section{Data description}

The description of the Intellectual Intelligence data shows that the average value reaches 93.85 with a standard deviation of 8.195 Histogram of the frequency of Intellectual intelligence scores

Table 1. Description of Intellectual Intelligence Data Statistics Intellectual Intelligence

\begin{tabular}{|l|r|}
\hline Valid & 96 \\
Missing & 0 \\
Mean & 93,85 \\
Std. Error of Mean &, 836 \\
Median & 93,00 \\
Mode & 92 \\
Std. Deviation & 8,195 \\
Variance & 67,157 \\
Skewness &,- 060 \\
Std. Error of &, 246 \\
Skewness &,- 557 \\
Kurtosis &, 488 \\
Std. Error of Kurtosis & 35 \\
Range & 76 \\
Minimum & 111 \\
Maximum & 9010 \\
Sum & \\
\hline
\end{tabular}

Based on the figure 1, it can be seen that the histogram bar graph has a normal curve because the curve is bell-shaped. This states that Intellectual Intelligence is categorized as moderate or good enough.

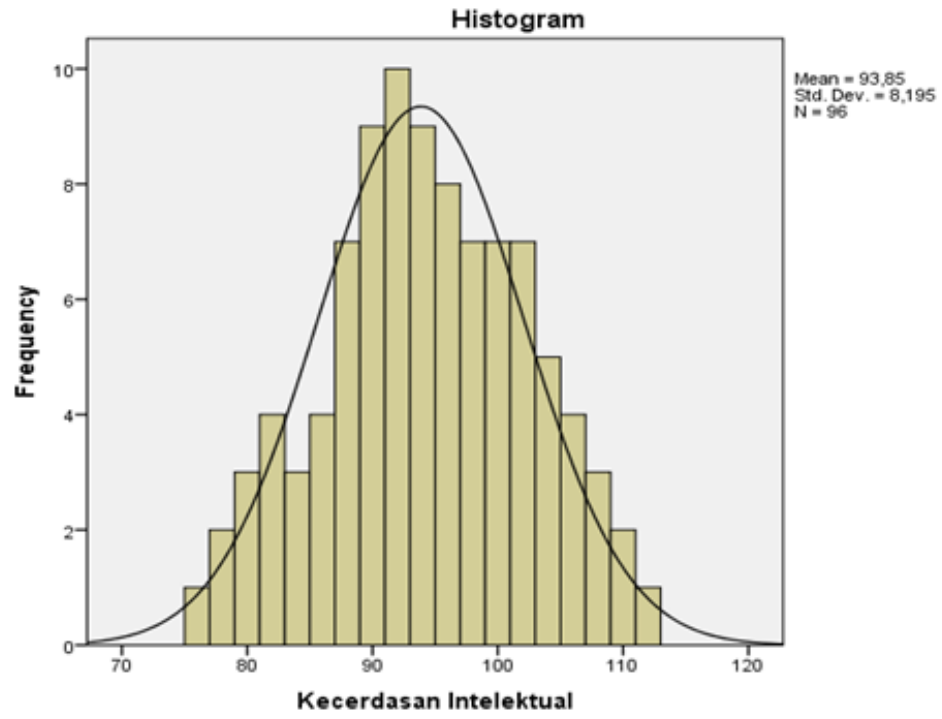

Figure 1. Intellectual Intelligence Score Histogram 
Table 2. Description data Adversity Quotient

\begin{tabular}{|l|r|}
\hline \multicolumn{2}{|c|}{ Statistics } \\
Adversity Quotient \\
\hline N $\quad$ Valid & 96 \\
Mean & 0 \\
Std. Error of Mean & 100,76 \\
Median &, 603 \\
Mode & 101,00 \\
Std. Deviation & 100 \\
Variance & 5,904 \\
Skewness & 34,858 \\
Std. Error of Skewness &,- 012 \\
Kurtosis & 246 \\
Std. Error of Kurtosis &,- 747 \\
Range &, 488 \\
Minimum & 25 \\
Maximum & 88 \\
Sum & 113 \\
\hline
\end{tabular}

The description of the Adversity Quotient data shows that the average value reaches 100.76 with a standard deviation of 5.904. Histogram of the frequency of Adversity Quotient scores.

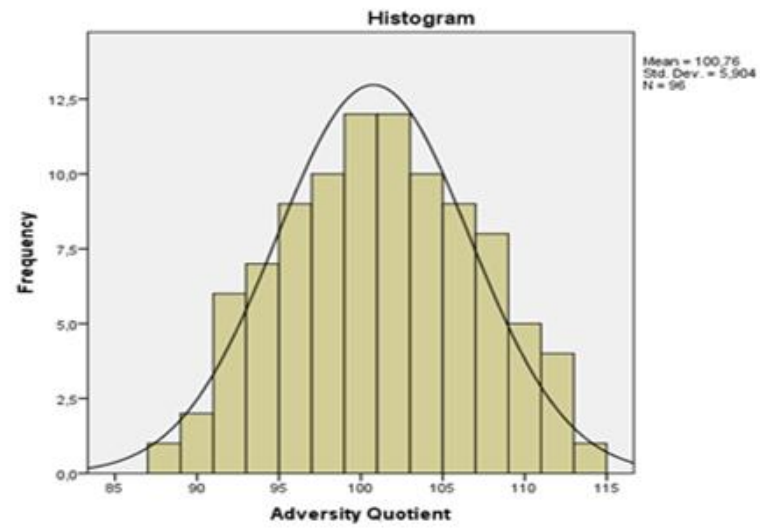

Figure 2. Histogram of Adversity Quotient Score

Based on the picture above, it can be seen that the histogram bar graph has a normal curve because the curve is bell-shaped. This means that the Adversity Quotient is categorized as moderate or good enough.

Table 3. Description of Learning Motivation Data Statistic Motivation to learn

\begin{tabular}{|l|r|}
\hline $\mathrm{N} \quad$ Valid & 96 \\
Mean & 0 \\
Std. Error of Mean & 99,86 \\
Median &, 664 \\
Mode & 100,00 \\
Std. Deviation & 100 \\
Variance & 6,506 \\
Skewness & 42,329 \\
Std. Error of Skewness &, 058 \\
Kurtosis &, 246 \\
Std. Error of Kurtosis & -513 \\
Range &, 488 \\
Minimum & 30 \\
Maximum & 866 \\
Sum & 116 \\
\hline
\end{tabular}


The description of the learning motivation data shows that the average value reaches 99.86 with a standard deviation of 6.506 Histogram of the frequency of learning motivation scores

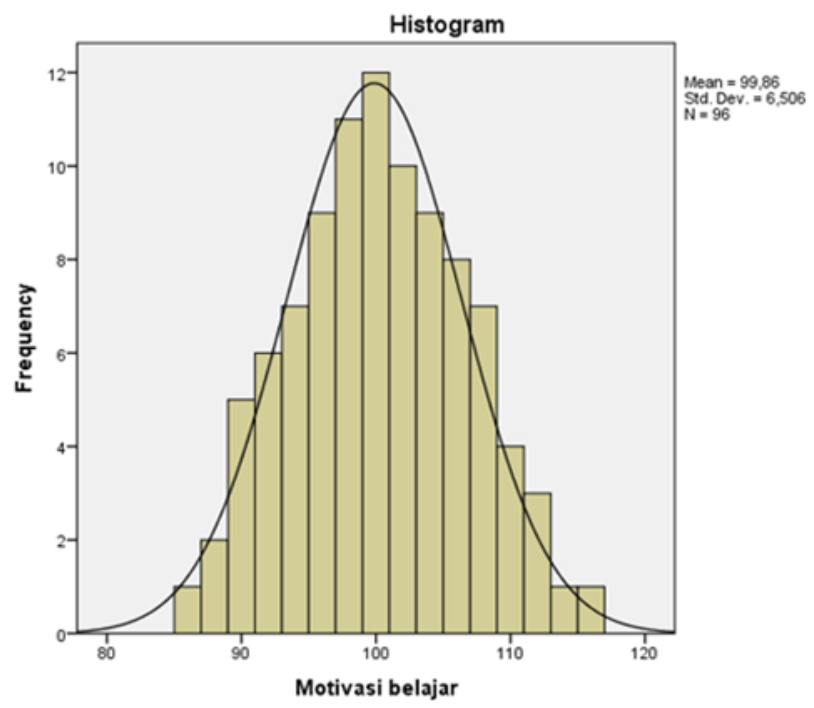

Figure 3. Histogram of Learning Motivation Score

Based on the picture above, it can be seen that the histogram bar graph has a normal curve because the curve is bell-shaped. This states that learning motivation is categorized as moderate or good enough.

\section{Linear Correlation Analysis}

Table 4. Linear Correlation Analysis

Model Summary

\begin{tabular}{|c|c|c|c|c|c|c|c|c|c|}
\hline \multirow{2}{*}{$\begin{array}{l}\text { Mod } \\
\text { el }\end{array}$} & \multirow[t]{2}{*}{$\mathrm{R}$} & \multirow{2}{*}{$\begin{array}{c}\mathrm{R} \\
\text { Square }\end{array}$} & \multirow{2}{*}{$\begin{array}{l}\text { Adjusted R } \\
\text { Square }\end{array}$} & \multirow{2}{*}{$\begin{array}{l}\text { Std. Error of the } \\
\text { Estimate }\end{array}$} & \multicolumn{5}{|c|}{ Change Statistics } \\
\hline & & & & & $\begin{array}{c}\text { R Square } \\
\text { Change }\end{array}$ & F Change & df1 & $d f 2$ & $\begin{array}{c}\text { Sig. F } \\
\text { Change }\end{array}$ \\
\hline 1 & $334^{\mathrm{a}}$ & 111 & 087 & 5,411 & 111 & 4,635 & 2 & 74 & 013 \\
\hline
\end{tabular}

a. Predictors: (Constant), Adversity Quotient, Kecerdasan Intelektual

Basis of decision making. If the value of $\mathrm{F}$ change $<0.05$ then it is correlated. If the value of $\mathrm{F}$ change $>$ 0.05 then it is not correlated. Because, the value of $\mathrm{F}$ change $0.013<0.05$. So we can conclude that the variables $\mathrm{X} 1$ and $\mathrm{X} 2$ are related to the variable $\mathrm{Y}$

\section{Statistical Hypothesis Test Results}

\section{Partial Test ( $t$ Test)}

The t-test is used to test the significance of the relationship between the $\mathrm{X}$ and $\mathrm{Y}$ variables partially or it can be said that the t-test basically shows how far one independent variable individually explains the dependent variable. If the statistic $t$ count $<$ statistic $t$ table, then $\mathrm{H}^{0}$ is accepted, and or if the statistic $\mathrm{t}$ count $>$ statistic $\mathrm{t}$ table, then $\mathrm{H}^{0}$ is rejected and or if the probability of significance $>0.05$ then $\mathrm{H} 0$ is accepted and or if the probability of significance is $<0.05$ then $\mathrm{H}^{0}$ reject.

Table 5. Partial test results

\begin{tabular}{|c|c|c|c|c|c|c|}
\hline \multicolumn{7}{|c|}{ Coefficients $^{a}$} \\
\hline \multirow{2}{*}{\multicolumn{2}{|c|}{ Model }} & \multicolumn{2}{|c|}{$\begin{array}{c}\text { Unstandardized } \\
\text { Coefficients }\end{array}$} & \multirow{2}{*}{$\begin{array}{c}\begin{array}{c}\text { Standardized } \\
\text { Coefficients }\end{array} \\
\text { Beta }\end{array}$} & \multirow[t]{2}{*}{$\mathrm{t}$} & \multirow[t]{2}{*}{ Sig. } \\
\hline & & $\mathrm{B}$ & Std. Error & & & \\
\hline \multirow{4}{*}{1} & (Constant) & 121,123 & 11,790 & & 10,273 &, 000 \\
\hline & Kecerdasan & & & & 2003 & \\
\hline & Intelektual & ,244 & ,082 & 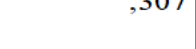 & 2,903 & ,004 \\
\hline & Adversity Quotient & 016 & ,114 & 015 & 2,141 & ,008 \\
\hline
\end{tabular}

Dependent Variable: Motivasi belajar 
First Hypothesis

$H_{a 1}: \beta_{1} \neq 0$; There is an influence of intellectual intelligence on learning motivation

$H_{01}: \beta_{1}=0$; There is no influence of Intellectual Intelligence on learning motivation

The results of the t-test for Intellectual Intelligence (X1) on learning motivation (Y) showed a value of sig.0.004. This means that the significance value is smaller than the probability value of $0.05(0.004<0.05)$ and tcount shows a value of 2.963 . This means that tcount $>t$ table $(2,963>1,98498)$. So the conclusion is that $\mathrm{H} 0$ is rejected and $\mathrm{Ha}$ is accepted, so it can be said that there is an influence of Intellectual Intelligence on learning motivation. Because the t-count is positive, if the Intellectual Intelligence variable increases, the learning motivation will also increase and vice versa if the Intellectual Intelligence variable decreases, the learning motivation will also decrease. Based on the analysis that intellectual intelligence is one of the determining factors that can affect student motivation.

Second hypothesis:

$H_{a 2}: \beta_{1} \neq 0$; There is a significant effect of Adversity Quotient on learning motivati

$H_{02}: \beta_{1}:=0$; There is no significant effect of Adversity Quotient on learning motivation.

The results of the Adversity Quotient (X2) t-test on learning motivation (Y) show the value of sig. 0.008 means that the significance value is smaller than the probability value of $0.05(0.008<0.05)$ and tcount shows a value of 2.141 . This means that tcount $>t$ table $(2.141>1.98498)$. So the conclusion is that $\mathrm{H} 0$ is rejected and $\mathrm{Ha}$ is accepted, so it can be said that there is an influence of Adversity Quotient on learning motivation. Because the t-count is positive, if the Adversity Quotient variable increases, the learning motivation will also increase and vice versa if the Adversity Quotient variable decreases, the teacher's learning motivation will also decrease.

\section{Simultaneous Test (F Test)}

The $\mathrm{F}$ test was conducted to determine whether all independent variables had the same effect on the dependent variable. If the statistic $\mathrm{F}$ count < statistic $\mathrm{F}$ table, then $\mathrm{H} 0$ is accepted; and if $\mathrm{F}$ statistic $>$ table $\mathrm{F}$ statistic, then $\mathrm{HO}$ is rejected; and if the probability is significant $>0.05$ then $\mathrm{HO}$ is accepted; and if the probability of significance $<0.05$ then $\mathrm{H} 0$ is rejected; F test results can be seen in the table.

Table 6. Simultaneous Test Results (F Test)

ANOVA

\begin{tabular}{|c|c|c|c|c|c|}
\hline Model & $\begin{array}{c}\text { Sum of } \\
\text { Squares }\end{array}$ & $\mathrm{df}$ & $\begin{array}{c}\text { Mean } \\
\text { Square }\end{array}$ & $\mathrm{F}$ & Sig. \\
\hline Regression & 369,081 & 2 & 184,541 & 4,699 &, $011^{b}$ \\
\hline 1 Residual & 3652,158 & 93 & 39,271 & & \\
\hline Total & 4021,240 & 95 & & & \\
\hline
\end{tabular}

Dependent Variable : Learning Motivation

b. Predictors: (Constant), Adversity Quotient, Intellectual Intelligence

Third hypothesis:

$H_{a 3}: \beta_{1} \neq 0$; There is a significant effect of Intellectual Intelligence and Adversity Quotient together on learning motivation

$H_{03}: \beta_{1}=0$; There is no significant effect of Intellectual Intelligence and Adversity Quotient together on learning motivation

From the ANOVA test or F test, the Fcount is 4.699 with a significance level of 0.011 . Ftable 3.94 is obtained by looking at table $\mathrm{F}$ with degrees $\mathrm{df}=2-1$ and $\mathrm{df}=\mathrm{nk}(\mathrm{df}=96-2)$ at a significance level of 0.05 . Because the probability (0.011) is much smaller than 0.05 and Fcount $>$ Ftable, this shows that $\mathrm{H} 0$ is rejected and $\mathrm{Ha}$ is accepted or there is a significant influence on Intellectual Intelligence and Adversity Quotient together on learning motivation. The results of this study are in line with the theory that has been found previously.

This research is in line with wirabhakti's opinion that there is a significant influence of intellectual intelligence on student learning achievement. Researchers recommend that school managers pay attention to and increase students' learning motivation which in turn can increase their intellectual intelligence so as to create learning achievement (Wirabhakti, 2019). (Sawaludin, 2021) revealed that there is a strong relationship between intellectual intelligence and student learning motivation, because intellectual intelligence is able to arouse student learning motivation, besides intellectual intelligence is the ability to think rationally by optimizing brain work as a person's basic competence. In detail, the factors that influence intellectual 
intelligence are: 1) nature; 2) maturity; 3) formation; 4) interest. According to that intellectual intelligence is analysis, logic and ratio which is a person's intelligence to store, receive and manage information into facts, indicators of intellectual intelligence include; easy to use calculations, good memory, easy to catch conversations and easy to draw conclusions. (Sulastyaningrum, 2019) also emphasized that one thing that can affect student achievement is intellectual intelligence. Then (Nur Rachmah et al., 2015) also revealed that besides intellectual intelligence, there is adversity intelligence that must be possessed by students. Adversity intelligence is an individual's ability to predict attitudes when in trouble or the ability to predict the individual's resilience and strength in working together in a team. Adversity intelligence greatly affects the success of students academically, such as having the motivation to complete tasks so that they excel in academic activities. So that it can be proven in this study, that intellectual intelligence and adversity quotient have a significant effect on students' learning motivation.

\section{Conclusions}

Intellectual Intelligence on learning motivation shows the value of sig.0.004. This means that the significance value is smaller than the probability value of $0.05(0.004<0.05)$ and tcount shows a value of 2.963 . This means that tcount $>t$ table $(2,963>1,98498)$. So it can be concluded that there is an influence of Intellectual Intelligence on learning motivation, meaning that if intellectual intelligence increases, learning motivation will also increase and vice versa. Adversity Quotient on learning motivation shows the value of sig. 0.008 means that the significance value is smaller than the probability value of $0.05(0.008<0.05)$ and tcount shows a value of 2.141. This means that tcount $>\mathrm{t}$ table $(2.141>1.98498)$. The conclusion is that there is an influence between Adversity Quotient on learning motivation, so if Adversity Quotient increases then learning motivation will also increase, and vice versa. Based on the ANOVA test or F test, the Fcount is 4.699 with a significance level of 0.011 . F table 3.94 is obtained by looking at table $F$ with degrees $\mathrm{df}=2-1$ and $\mathrm{df}=\mathrm{n}-\mathrm{k}$ $(\mathrm{df}=96-2)$ at a significance level of 0.05 . This means that there is a significant influence between Intellectual Intelligence and Adversity Quotient together on learning motivation.

This study has proven that not only intellectual intelligence has an effect on students' learning motivation, but there are other intelligences that have a positive effect on motivation, namely the adversity quotient. The higher the intellectual intelligence and adversity quotient, the more it can increase students' learning motivation. The most influential variable with motivation is intellectual intelligence, then adversity quotient. With this research, it is hoped that all educational staff, including educators, can pay attention to and develop intellectual intelligence, the adversity quotient of students in the learning process. Because, based on the research that has been done, the two intelligences have a big enough influence in motivating student learning so that students can improve their achievements, both academically and non-academicly.

\section{References}

Akimas, H. N., \& Bachri, A. A. (2016). The Influence of Intellectual Intelligence (Iq), Emotional Intelligence $(\mathrm{Eq})$, Spiritual Intelligence $(\mathrm{Sq})$ on the Performance of Inspectorate Employees of South Kalimantan $\begin{array}{lllll}\text { Province. Journal of } & \text { 259-272. }\end{array}$ http://jwm.ulm.ac.id/id/index.php/jwm/article/view/99

Amry, S. (2020). Effective Learning Process in Shaping Intellectual Intelligence and Learning Motivation in Students at Mahad Ali bin Abi Talib Yogyakarta. $\quad$ Literature (Journal of Educational Science), 11(2), 96. https://doi.org/10.21927/literasi.2020.11(2).96 103

Arif, M. F., Askandar, N. S., \& Mahsuni, A. W. (2020). Analysis of the Influence of Perceptions of the Public Accountant Profession, Motivation and Adversity Intelligence of Students at the Islamic University of Malang on Interest in Becoming a Public Accountant.E-Jra,9(1),60-74. http://www.research.unisma.ac.id/index.php/jra/article/view/5421

Ayu, P., \& Pratiwi, C. (2020). Improving Intellectual Intelligence of Early Childhood Through the Media of Guessing the Picture-Based Professional Game. 3(3), 416-424.

Benu, T. I. A., \& Nugroho, P. I. (2021). The Effect of Emotional Intelligence and Learning Motivation on Learning Achievement with the Level of Accounting Understanding as an Intervening Variable. Journal of Professional Accounting, 12(1), 224. https://doi.org/10.23887/jap.v12i1.32829

Di Perri, G., Cazzadori, A., Vento, S., Bonora, S., Malena, M., Bontempini, L., Lanzafame, M., Allegranzi, B., \& Concia, E. (2018). Comparative histopathological study of pulmonary tuberculosis in human immunodeficiency virus-infected and non-infected patients. Tubercle and Lung Disease, 77(3), 244-249. https://doi.org/10.1016/S0962-8479(96)90008-8 
Gustina, M., \& Ali, H. (2020). Analysis of Low Toilet Ownership in Muara Aman Village, Pasemah Air Keruh District, Empat Lawang Regency. Journal of Nursing and Public Health, 8(1), 73-78. https://doi.org/10.37676/jnph.v8i1.11016

Kristianawati, R., \& Wafirotin, K. Z. (2018). The Influence of Intellectual Intelligence, Emotional Intelligence, Spiritual Intelligence and Learning Behavior on the Level of Accounting Understanding. ISOQUANT: Journal of Economics, Management and Accounting, 1(1), 79. https://doi.org/10.24269/iso.v1i1.47

Mamangkey, L. A. G., Tewal, B., Trang, I., Sam, U., \& Manado, R. (2018). The Influence of Intellectual Intelligence (Iq), Emotional Intelligence (Eq), and Social Intelligence (Sq) on Employee Performance at Bank Bri Manado Regional Office. EMBA Journal: Journal of Economic Research, Management, Business And Accounting, 6(4), 3208-3217. https://doi.org/10.35794/emba.v6i4.21294

Merianah. (2019). The Effect of Emotional Intelligence and Adversity Quotient on Mathematics Problem Solving Ability of SDIT IQRA '1 Students in Bengkulu City. 04(01), 29-35.

Nur Rachmah, D., Dwi Mayangsari, M., \& Noor Akbar, S. (2015). Learning Motivation as a Mediator of the Relationship between Adversity Intelligence and Academic Procrastination in Students who are Actively Organized. Journal of Educational Horizons, 2(2), 211-221. https://doi.org/10.21831/cp.v2i2.4826

Pasek, N. S. (2017). The Effect of Intellectual Intelligence on Accounting Understanding With Emotional Intelligence And Spiritual Intelligence As Moderating Variables. Scientific Journal of Accounting, 1(1), 6276. https://doi.org/10.23887/jia.v1i1.9983

Sairan, I. (2020). Ethnomathematics of the Pasemah Tribe Turbid Water Four Lawang Based on Mathematical Concepts and Principles. Raflesia Journal of Mathematics Education, 05(02), 130-136.

Sarnoto, A. Z., \& Romli, S. (2019). The Influence of Emotional Intelligence (Eq) and Learning Environment on Student Motivation at Sma Negeri 3 South Tangerang. Andragogy: Journal of Islamic Education and Management of Islamic Education, 1(1), 55-75. https://doi.org/10.36671/andragogi.v1i1.48

Sawaludin., Fitriah, A., Basariah, I Nengah A. T. (2021). Correlation Of Learning Motivation To The Intellectual Intelligence Of Students In SMA Negeri 1 Mataram Correlation Of Learning Motivation To The Intellectual Intelligence Of Students In SMA Negeri 1 Mataram. 13(1), 13-22.

Srihartini, E., Fatmasari, R., \& Rosita, T. (2021). The influence of adversity intelligence and work performance on teacher professionalism. Journal of Counseling and Education, 9(1), 65. https://doi.org/10.29210/149300

Thamaria, N. (2018). The Relationship of Learning Motivation and Intellectual Intelligence With Pai Learning Outcomes Inelementary School 5 Saentis Deli Serdang. Zitteliana, 18(1), 22-27.

Tinggi, S., Islam, A., Syamsul, S., Gunungpuyuh, U., \& West, J. (2019). The Effect of Intellectual Intelligence and Learning Motivation on Student achievement. Journal of Islamic Education Management (JMPI), 04, $22-42$.

Wayan, J. A., Ketut., Suma, I. S. (2017). Contribution of Learning Motivation, Emotional Intelligence, and Intellectual Intelligence to Physics Learning Achievement. Journal of Physics Education. 